\title{
Erratum to: Justification of Koiter's Shell Model Using Gamma Convergence
}

\author{
N. Sabu $\cdot$ J. Raja
}

Published online: 10 December 2013

(C) The National Academy of Sciences, India 2013

Erratum to: Proc. Natl. Acad. Sci., India, Sect. A Phys.

Sci. (2013) 83(3):257-264

DOI 10.1007/s40010-013-0080-x

The original article has been published with incorrect author name. The author's name should read as "J. Raja".

The online version of the original article can be found under doi: 10.1007/s40010-013-0080-x.

N. Sabu $(\bowtie) \cdot$ J. Raja

Department of Mathematics, Indian Institute of Space Science and Technology, Thiruvananthapuram 695547, India

e-mail: sabu@iist.ac.in 